\title{
A hormonális rendszer válsága: az endokrin diszruptorok egészségügyi hatásai
}

\author{
Csaba György dr. \\ Semmelweis Egyetem, Általános Orvostudományi Kar, Genetikai, Sejt- és Immunbiológiai Intézet, Budapest
}

\begin{abstract}
Az endokrin diszruptorok a környezetből az állati (emberi) szervezetbe jutó olyan természetes vagy mesterséges molekulák, amelyek hormonreceptorokhoz kapcsolódva serkentik vagy gátolják adott sejtek tevékenységét, hormonok vagy receptorok elóállítását, illetve transzportját. Ha kapcsolódásuk valamely kritikus periódusban történik, hibás hormonális imprintinget hoznak létre életre szóló következményekkel, mint hormonbefolyásolt sejtmúködések megváltozása, betegségekre való hajlam manifesztálódása vagy betegségek megjelenése, ezért orvosi-egészségügyi jelentőségük van. Az endokrin diszruptorok száma nagy és éppúgy, mint felhasználásra kerülő mennyiségük, növekszik, ezáltal számos, felnőttkorban megjelenő kórkép (például daganat) visszavezethető perinatalis kori endokrin diszruptorártalmakra. Tartós hatásuk alapvető emberi jellegzetességek (például menarche időpontja) megváltozásához vezet. Az A- és D-vitamin is hormon (exohormon) és kívülról bejutva a szervezetbe endokrin diszruptorok lehetnek. Az endokrin diszruptorok által kiváltott imprinting az utódgenerációkra epigenetikusan átadódik, így befolyásolhatja az utódok gyógyszerérzékenységét is. Ha az epigenetikus öröklődés tartóssá válik, annak humánevolúciós jelentősége is lehet.
\end{abstract}

Orv Hetil. 2017, 158(37): 1443-1451.

Kulcsszavak: endokrin diszruptorok, hormonális imprinting, perinatalis időszak, epigenetika, fitoösztrogének, zsíroldékony vitaminok

\section{The crisis of the hormonal system: the health-effects of endocrine disruptors}

The endocrine disruptors are natural or arteficial molecules wich are present in the animal (human) environment and entering into the organism. They are bound by hormone receptors, simulating or inhibiting the normal hormonal message. This way they are able to stimulate or hinder the function of the given cell, as well as the synthesis and transport of hormones or receptors. They can cause faulty hormonal imprinting in critical periods of development with lifelong consequences, as alteration of hormone-influenced cell functions, inclination to or manifestation of diseases, so they have medical importance. The number of endocrine disruptors as well as their amount are large and continously growing. Numerous, in adult age manifested disease (e.g. malignant tumors) can be deduced to perinatal harms. Their long-lasting effect can cause the alteration of basal human developmental characteristics (e.g. start of menarche). Vitamins A and D are hormones (exohormones) and could be endocrine disruptors. Perinatal imprinting caused by endocrine disruptors is transmitted to the progenies epigenetically, which also can influence the drugsensitivity of offspring' receptors. If the epigenetic change is continuously transmitted to the progeny generations, this could have human-evolutionary importance.

Keywords: endocrine disruptors, hormonal imprinting, perinatal period, epigenetics, phytoestrogens, lipid soluble vitamins

Csaba, Gy. [The crisis of the hormonal system: the health-effects of endocrine disruptors]. Orv Hetil. 2017; 158(37): 1443-1451.

(Beérkezett: 2017. július 17.; elfogadva: 2017. augusztus 10.)

Az Orvosi Hetilap alapításának 160. évében, a Szerkesztőség felkérésére készült tanulmány. 


\section{Rövidítések}

ADHD = figyelemhiányos hiperaktivitási zavar; BPA = bisphenol A; DES = dietil-stilbösztrol; DDT = diklór-difenil-triklóretán (rovarméreg); DNS = dezoxiribonukleinsav; ED = endokrin diszruptor; $\mathrm{RNS}=$ ribonukleinsav; $\mathrm{UV}=$ ultraibolya

\section{A receptor-hormon kapcsolat}

$\mathrm{Az}$ endokrin rendszer múködéséhez mind az endokrin mirigyek által termelt hormonok, mind a hormonokat felismerő receptorok szükségesek, illetve azok a transzmissziós utak, amelyeken át a hormon üzenete a végrehajtás helyére eljut. A klasszikus endokrin mirigyek és hormonjaik felismerése óta számtalan új hormontermelő sejtet és hormont ismertek fel, és előbb vagy utóbb mindig megtalálták receptoraikat is, sőt árva receptorok is vannak, amelyek hormonja még nem ismert. A receptorok alapvető jelentőségüek az endokrin rendszerben, nélkülük a hormonok nem tudnak hatni. A plazmamembránban vagy a sejtmagban (és citoplazmában) elhelyezkedő jelfogók rendszerint specifikusak, azonban bizonyos körülmények között megtéveszthetők hormonokhoz hasonló molekulák által. Ezek lehetnek a szervezeten belül termelődő hormoncsalád egyéb tagjai vagy a környezetből a szervezetbe kerülő rokon molekulák (szintetikus hormonok, hormonanalógok, gyógyszerek, ember által elóállított vagy természetes környezetszenynyezők, ipari termékek). Mivel utóbbiak rombolják az endokrin rendszer normális körülmények között tökéletesen beállított rendszerét, az endokrin diszruptor (ED) nevet nyerték el. A receptorok specificitása az élet folyamán változó, így vannak kritikus periódusok, amikor a megtévesztés lehetősége fokozott, sőt ilyenkor az idegen, de kapcsolódó molekula által okozott hiba életre szólóan bevésődik (hormonális imprinting).

$\mathrm{Az}$ anyaméhben is múködik a magzat endokrin rendszere, azonban az anyai hormonok által befolyásolt módon. A születéssel azonban a magzati endokrin rendszernek is át kell állnia a saját vezérlésre, tehát a saját maga által termelt hormonokat kell felismernie az újszülött receptorainak. Az átállás a perinatalis kritikus periódusban történik meg, amikor végbemegy a hormonális imprinting, amely életre szólóan határozza meg a receptor és a hormon további viszonyát, elsősorban a receptor kötési kapacitását [1]. Ez egy minőségileg és mennyiségileg pontosan beállított mechanizmus, amelyet azonban ilyenkor megzavarhat az idegen, de kapcsolódni képes molekulák jelenléte, így hibás hormonális imprinting jön létre akár egyetlen receptor-hormon kapcsolat által. Mivel a hiba bevésődik, a későbbiekben a saját hormonra is hibás reakció lép fel. Ez felnőttkorban a receptort hordozó sejt hibás múködésében mutatkozik meg, ami betegségre való hajlamot, illetve manifeszt betegséget jelent $[2,3]$.

Hibás hormonális imprinting alkalmával epigenetikai változás jön létre, ami azt jelenti, hogy a bázissorrend változása nélkül a DNS szabályozásának változása következik be a DNS vagy a hiszton metilációja, illetve bizonyos RNS-ek változása miatt. Bár csak néhány generáció vizsgálata történt meg, ezekben ugyanúgy sejtről sejtre, sőt generációról generációra öröklődik, mint a bázissorrend változása (mutáció) [4].

Kritikus periódusok a perinatalis időszakon kívül is vannak. Bár a legkritikusabbnak a perinatalis látszik, az elválasztás és a pubertás időszaka ugyancsak kritikus [5]. Úgy tűnik, hogy az egész élet folyamán imprintálhatók a folyamatosan osztódó sejtek (például a vérképzők), de talán - különböző mértékben - minden sejt [6]. A „talán” azt jelenti, hogy nehezen bizonyítható, hogy bármely, felnőttben lévő sejt ôse még perinatalisan nem kapott némi hibás imprintinget, tehát hormonokra való eltérố érzékenysége ennek tulajdonítható. Ez egyúttal azt is jelenti, hogy az ED-k minden életkorban tudnak kapcsolódni receptorokkal, ezáltal bármikor képesek káros tevékenységet kifejteni.

\section{Történelmi elözmények}

Az ED-k és hatásaik (veszélyeik) kezdeti felismerése nem orvosi kutatások, illetve megfigyelések eredményeként történt meg. Rachel Carson 1962-ben megjelent Néma tavasz címú könyvében hívta fel a figyelmet arra, hogy a természetben felhalmozódó vegyi anyagok, elsősorban rovarirtók hatására kipusztulnak egyes állatok (például madarak), ami szinte helyrehozhatatlan kárt okoz az állatvilágban [7], és ez arra késztette az illetékes szerveket, hogy betiltsák a DDT használatát. Ugyanakkor a megfigyelésekből nem vontak le általános következtetéseket, holott már korábban ismertté vált, hogy szteroidhormonokkal az ember által fogyasztott tenyészállatok súlya növelhető, miközben reproduktív funkcióik károsodnak. Ugyancsak ekkor már alakult, illetve kipróbálásra került a fogamzás gátlása szteroidok által, és 1938-ban szintetizálták a dietil-stilbösztrolt (DES-t), egy, az ösztradiolhoz hasonló hatású molekulát, amellyel megakadályozható a koraszülés és vetélés. Mivel a kezelés látszólag egészségesebb és objektíve súlyosabb újszülötteket eredményezett, propagálták indikáció nélküli széles körü alkalmazását is. A felelőtlen propaganda csak az Egyesült Államokban mintegy 5-10 millió terhes nő DES-kezeléséhez vezetett. Ezen nők leányaiban igen nagy gyakorisággal lépett fel a hüvelyben világos sejtes carcinoma körülbelül 15-20 évvel a kezelések után, és egyéb kóros nemi elváltozások jelentek meg fiúkban és lányokban egyaránt, miközben az anyák hajlama emlőtumorra fokozódott [8]. Az általános következtetést megint nem vonták le, így szabad utat engedtek a fogamzásgátlók fejlesztésének és alkalmazásának, ami újabb problémákhoz vezetett.

A DES alkalmazása orvosi előírásra történt, azonban voltak tömegméretű szándékolatlan alkalmazásai is a hormonszerú molekuláknak, mint a polichlorinált bifenilek (PCB-k), illetve dibenzofuranok (PCDF-ek), ame- 
lyek az ösztrogén vagy arilhidrokarbon (például benzpirén) receptorokra hatnak. Ezek Japánban és Tajvanon okoztak tömeges magzati retardációt és neurológiai problémákat az érintett anyák utódaiban [8].

A természetes vizekben felhalmozódó, emberi vizelettel kiválasztott vagy agrotechnikailag alkalmazott szteroidok súlyos elváltozásokat hoztak létre a vízi élőlények reproduktív vagy pajzsmirigy által befolyásolt rendszerében. Mindez - tehát az emberi szervezetben és az ember környezetében fellépő zavar - felhívta a figyelmet arra, hogy a szervezetbe bevitt vagy a környezetből természetes úton bejutó hormonszerű molekulák kapcsolódni tudnak hormonreceptorokkal, ezáltal befolyásolják a szervezetek életfolyamatait. A múlt század 90-es éveiben kezdték szisztematikusan vizsgálni a legkülönbözőbb környezetszennyezők egészségügyi hatásait, azaz az általános toxikológiai vizsgálatok mellett kiemelten tanulmányozták az endokrin-toxikológiai hatásokat. A jelen század elején ismerték fel, hogy globális problémáról van szó, amely ellen hatékony eszközökkel kell harcolni. Ekkorra már az orvosi megfigyelések tömege állt rendelkezésre ezen környezetszennyezők egészségkárosító hatásáról, és az „endokrin diszruptor” elnevezés is polgárjogot nyert.

\section{Az endokrin diszruptorok}

A WHO Európai Bizottság meghatározása szerint [9] „endokrin diszruptor valamely exogén anyag (vagy keverék), amely befolyásolja az endokrin rendszert és ennek következményeként káros egészségügyi hatások észlelhetők egy intakt szervezetben vagy annak utódaiban, vagy egyes szubpopulációkban”. A meghatározás kevéssé konkrét, így lehetôséget ad a besorolások eltérő voltára. Mégis jobbára idesorolják [10] a pesticidek egyes csoportjait (például DDT), ipari hormonhatású anyagokat (például dioxinok, polichlorinált bifenilek), ftalátokat, fenolokat (például bisphenol A), szintetikus, hormonhatású gyógyszereket és a növényi hormonok egyes csoportjait (fitoösztrogének) [11, 12]. Már ez a korántsem teljes felsorolás is mutatja az ED-k heterogenitását, és jelzi, hogy az ED-k esetében csak egyvalami azonos: a hormonszerü hatás. Ugyanakkor endokrin diszruptor csak olyan anyag lehet, ami kívülről jut be a szervezetbe. Bár egyesek a meghatározáshoz hozzáteszik, hogy ember alkotta mesterséges anyagokról van szó, ez nem szükségszerü. A fitoösztrogének természetes molekulák, és a dioxinok vagy a benzpirén a környezetbe kerülhetnek emberi beavatkozás nélkül is (például tűzhányók működése által). Az ED-k tehát az ember létrejötte előtt is már jelen voltak a földi környezetben, csak egészségügyi hatásaik nem voltak ismertek, erre valóban korunk emberi tevékenysége és annak káros hatása hívta fel a figyelmet.

$\mathrm{Az}$ egészséges szervezetben génszinten meghatározott az endokrin szervek (sejtek) fejlődése és múködése, a receptor és a hormon kapcsolódása és ennek eredményeként a szervezet számára optimális válasz. Ezt a ren- det képes megzavarni az endokrin diszruptor azáltal, hogy:

- kapcsolódik a receptorhoz, de nem a szervezet szükséglete által kijelölt mértékben vagy időben, ezáltal atípusos választ, illetve betervezetlen reakciót vált ki;

- kapcsolódik a receptorhoz, de nem aktiválja azt, ugyanakkor lehetetlenné teszi a fiziológiás hormon kapcsolódását, ezáltal a rendezett választ;

- kapcsolódik a transzportfehérjékhez a természetes hormon helyett, így megzavarja a hormonhatás útját;

- kapcsolódik a hormonszintézis enzimjeihez, így megzavarja a fiziológiás hormon termelődését és/vagy lebontását;

- megzavarhatja a hormonreceptorok termelődését .

$\mathrm{Az}$ endokrin diszruptor a fiziológiás hormonénál lényegesen kisebb dózisban is képes megzavarni az endokrin rendszer múködését, ugyanakkor a fiziológiásnál lényegesen nagyobb dózisban is bekerülhet a szervezetbe. Mivel az endokrin rendszer egyes tagjai (hormonjai) a rendszeren belül is hatnak, egyetlen hormon termelödésének, illetve kötődésének hibája az egész rendszerre kihathat.

Az ED-k támadáspontja elsősorban a hormonreceptor, ugyanis ez ismeri fel - tévesen - az ED-t és továbbítja annak üzenetét. Minden hormonnak megvan a saját receptora, amely lehet egyedi, de vannak receptorcsaládok is. Az ED-k szempontjából utóbbiak a legsérülékenyebbek, mert bár különböző hormonokat kötnek, de lehetnek (vannak) átfedések is, éppen ezért alkotnak családot. Ilyen a szteroidreceptor-szupercsalád, amely magában foglalja a nemihormon-receptorokat, a mellékvesekéreg-hormonreceptorokat, a pajzsmirigyhormonok receptorát, a D- és A-vitamin receptorát, a xenobiotikum-receptorokat és a peroxiszómaproliferátor receptort. Már a múlt század végén 150-re becsülték a családba tartozó receptorok számát [13], amelyek nagy része emberben megtalálható. Ezen receptorcsalád tagjait tudja legkönnyebben „becsapni” valamely ED, amely maga is szteroid jellegú vagy ahhoz hasonlóan hat a receptoron. Ennek köszönhető, hogy a legtöbb megfigyelés a reprodukció területén van, amihez azonban az is hozzájárul, hogy az itt bekövetkező hibák relatíve könnyen felismerhetők. A reprodukciós rendszer mellett a pajzsmirigyre vonatkozó ED-hatások ismerete dominál, illetve vannak adatok az agy, a zsír- és cukoranyagcsere, illetve az immunrendszer vonatkozásában is.

Mivel az egyedfejlődés folyamán a receptorok specificitása eltérő (imprinting és kritikus periódusok), az ED-k által kiváltott káros hatások mértéke és formája is eltérő lehet $[14,15]$. Legsúlyosabb hatásokkal a magzati és perinatalis életkorban lehet számolni, mert vagy a fejlődési folyamatok zavara lép fel, esetleg már a születéskor is észlelhető következményekkel, vagy a hibás imprinting révén csak később manifesztálódó kórképek jelenhetnek meg (funkcionális teratogenitás). Ugyancsak fokozottan érzékeny periódus az elválasztási időszak [16, 17] és a pubertás [18-23]. 


\section{Az ED-k hatása az emlős- (emberi) szervezetre}

Az utóbbi évtizedekben több mint 100000 új vegyi anyag került bevezetésre az emberi környezetben és felhasználásban, amelyek jelentékeny része endokrin diszruptorként van nyilvántartva, illetve vár nyilvántartásra. Lehetetlen tehát hatásaikat is említve mindegyiket felsorolni. Helyesebbnek látszik, ha számba vesszük, a teljesség igénye nélkül, azokat a szerveket és szervrendszereket, amelyeket az ED-k támadnak, hogy fel lehessen mérni a hatás erejét és szélességét.

\section{A reprodukciós rendszer}

$\mathrm{Az}$ ED-k több ponton is támadják a reprodukciós rendszert, így mint inhibitorok beavatkoznak a szteroid nemi hormonok bioszintézisébe és metabolizmusába [24]. Ezenkívül kötődnek a transzkortinhoz és a szexhormonkötő globulinhoz, amelyek a vér általi transzportot bonyolítják le és közvetlenül kapcsolódnak a szexhormonreceptorokhoz, amelyek a válasz előhívásáért felelősek. Újabb adatok szerint kisspeptin szabályozza a gonadotropin felszabadulását, és ez a molekula érzékenyen reagál ED-kre [24].

A reprodukciós rendszert befolyásoló ED-k lehetnek ösztrogén vagy (anti)androgén hatásúak. Előbbiek kiemelkedő (leginkább tanulmányozott) képviselője a múanyagiparban rendszeresen felhasznált bisphenol A (BPA), míg utóbbiakat a vinclozolin, egy pesticid reprezentálja leginkább. Vannak úgynevezett jóindulatú ED-k, például a szójafitoösztrogének (genistein, daidzein), amelyek csökkentik az osteoporosis, szívbetegségek, emlőrák kockázatát és a menopauzális szimptómát, ugyanakkor káros hatásaik is ismertek [25-27].

Bizonyos esetekben az ED beleszól magába a nemi szerv kialakulásába, tehát már születéskor észlelhető morfológiai elváltozást okoz (hypospadiasis, cryptorchidismus), más esetekben csak funkcionális zavart idéz elő, amelynek hatása csak ivarilag érett korban mutatkozik meg (tumorképződés vagy funkcionális teratogenitás, infertilitás) [28, 29].

Terhesegér-kísérletekben BPA hatására az utódok prosztatája 30\%-kal nőtt nagyobbra, miközben a spermiumszám jelentősen csökkent. Emberben a krónikus BPA-hatás (az átlagpopuláció 93\%-ában találtak BPA-t a vizeletben) előrehozta a pubertást és növelte az emlőrákgyakoriságot [30]. Az erectilis diszfunkció a múanyagiparban dolgozó férfiak esetében hétszer gyakoribb volt, mint az átlagpopulációban, miközben csökkent a libidó és általában a szexuális élettel való elégedettség [31, 32]. Állatkísérletekben éppúgy, mint emberben, a DES és pesticidek növelik a cryptorchidismus előfordulását [3335]. Mindez együttesen növeli az infertilitást. A transgender egyedek száma nő az ED-k hatására [36, 37]).

A mezőgazdaságban felhasznált ED-k (ilyen a vinclozolin és atrazin is) hatására nőtt a hypospadiasis és cryp- torchidismus gyakorisága, és csökkent a spermiumok száma, valamint fertilizációs képessége, ami által gyakoribbá vált a férfi sterilitás [38].

A gyümölcsök és zöldségek mintegy 27\%-ában találtak egy vagy több pesticidet, amelyek valószínúleg szerepet játszanak az emlő- és prosztatarákok szaporodásában.

Állatkísérletekben bizonyított, hogy perinatalis benzpirén- vagy allylestranolkezelés alapvetően befolyásolja a felnőttkori szexuális aktivitást [39], és egyes ED-k (például benzpirén) szexuális hatása generációkon át öröklő$\operatorname{dik}[40]$.

\section{A pajzsmirigy}

BPA, ftalátok, brominált égésgátlók és perfluorinált kemikáliák rendelkeznek pajzsmirigydiszruptor hatással [41]. Hatásuk érinti a pajzsmirigyhormonok bioszintézisét, metabolizmusát és természetesen kötődését, így akcióját is, valamint e hormonok hatása alatt álló szervek (sejtek), így az agy múködését [42,43]. Különösen kifejezett a hatásuk a kritikus periódusokban [44]. Polichlorinált bifenilek, dioxinok és furanok hypothyreosist váltanak ki állatkísérletekben, és a környezetben előforduló dózisban is megbontják a humán pajzsmirigy-homeosztázist $[45,46]$.

\section{Az agy fejlödése és müködése}

Mivel az agy rendelkezik szexuálhormon- és pajzsmirigyhormon-receptorokkal, ezek a hormonok befolyásolják fejlődését (szexuális dimorfizmus) és múködését, indokoltnak látszott az ED-k vizsgálata is. Kiderült, hogy perinatalis kezelés ED-kkel jelentősen befolyásolja a felnoott kísérleti állatok szexuális magatartását és tanulási képességét [47]. A praeopticus area és a locus coeruleus térfogata nőtt. Az anya (patkány) perinatalis BPA-kezelése megváltoztatta a magatartást az utódokban: miközben a kontrollokban szexfüggő volt a magatartás, a különbség megszűnt BPA-expozíció után. A BPA ugyancsak befolyásolta az anyai magatartást [48]. Ez emberben is igaznak látszik, mert szignifikáns összefüggést találtak a vizelet BPA-szintje és számos magatartási eltérés (szorongás, antiszociális magatartás, oppozíciós zavarok) között $[49,50]$. Szintén befolyásolta az ED-expozíció az agresszivitást, figyelemhiányt és hiperaktivitást (ADHD), depressziót, különösen, ha az expozíció in utero történt [51]. Ugyanakkor a hormonális imprinting perinatalisan, illetve serdülőkorban hasonló hatásokat vált ki [52, 53].

\section{Az immunrendszer}

Az ED-k befolyásolják a citokin- és immunglobulin-szintézist, valamint az immunsejtek aktivitását és túlélését, továbbá közremúködnek az autoimmun betegségek kialakulásában [54]. Növelik az allergiás jelenségek (példá- 
ul asztma) előfordulását is. Immunoszuppresszív hatásuk jelentős. Egyesek, mint a BPA, befolyásolják a T- és Bsejtek, valamint a dendritikus sejtek funkcióját [55]. Fokozzák a gyulladást, valamint a hajlamot gyulladásos és különösen légúti betegségekre. Számos autoimmun betegség előmozdítói, mint az l-es típusú diabetes, thyreoiditis, rheumatoid arthritis, szisztémás lupus erythematodes [56]. Befolyásolják az immunsejtek endokrin funkcióját.

\section{Megbeszélés}

Anélkül, hogy egyenként vizsgálnánk a fenti adatokat, megállapítható, hogy az endokrin diszruptorok alapvetően befolyásolják az emberi szervezetet, illetve annak endokrin rendszerét. A hatás iránya - ritkán - lehet előnyös, túlnyomó többségében azonban hátrányos. Természetesen ezt a megállapítást az is befolyásolja, hogy többségében a hátrányos jelenségeket mérték fel, mert ezeknek nagyobb volt az orvosi jelentősége.

Nemcsak sokfajta ED van, de ezek száma az ipar igényeinek növekedésével rohamosan nő. Ezzel párhuzamosan nő mennyiségileg a már ismert ED-k felhasználása. Az egyik legismertebb (leginkább kutatott) $\mathrm{ED}$ az ösztrogénhatású BPA, amelyből már most is világszerte több mint 5,5 millió tonnát állítanak elő, és ez a mennyiség mintegy 7\%-kal nő évente, mert széleskörüen alkalmazzák a múanyagiparban, mint plastcizert (lágyító, képlékenyítő). Ezért megjelenik a cumispalackoktól kezdve az orvosi eszközökön és vízvezetékcsöveken át a konzervdobozok belső borításáig, a kozmetikumoktól a fogtömésekig mindenben, ami szükséges és korszerü. Az agrotechnikában felhasznált pesticidek, herbicidek és inzekticidek túlnyomó része antiandrogén. Használatuk folyamatosan nő, mindössze három év alatt, például 1961 és 1964 között, Európában 0,5kg/hektárról 2 kg/hektárra. Az ED-k elóállításának és felhasználásának növekedése megállíthatatlannak látszik, mert elvárja az emberiség jóllétigénye és követeli a rohamosan szaporodó emberiség eltartása [57].

Egyetlen sejtnek sokféle szteroidra van receptora, és egyetlen szteroidhormonnak sokféle sejtre van hatása. $\mathrm{Ez}$ azt is jelenti, hogy egyetlen ED szerteágazó hatást fejthet ki egy szervezetben vagy egy populációban. Ugyanaz a receptor sokféle ED-t tud felismerni és vele kapcsolódni, ezáltal az ED-hatások kombinálódhatnak is. Minél többféle ED jelenik meg a környezetben, annál valószínúbb a kombináció, így a hatásszélesség növekedése is. Ha például egy képzeletbeli étteremben sok a helyiség levegójében a benzpirén és dioxin, mert sokan dohányoznak, és a vendég alig egy órával ezelőtt kapott ösztradiolinjekciót, és most hormonkezelt állatból készült fasírozottat eszik szójaszósszal (genistein), amihez D-vitaminnal dúsított tejet iszik, majd (szójával dúsított) fagylaltot fogyaszt, máris összejött néhány ED, amelyek önállóan vagy kombináltan hatnak az egyed szteroidreceptoraira. A szituáció egyáltalán nem lehetetlen, sőt en- nél cifrább helyzet is elképzelhető. Ebben az egyszerü helyzetben is hathatnak azonban az ED-k kombináltan, de ki is szoríthatják egymást a receptorokról. Egy olyan versenyhelyzet áll elő, mint a fiziológiás hormon és egyetlen ED között, tehát az alaphelyzetben.

Az endokrin diszruptorok felsorolásakor nem szokták említeni a zsírban oldódó vitaminokat, holott az A- és D-vitamin megfelel ennek a kategóriának, és besorolásuk orvosi szempontból nagyon fontos. Receptoraik a szteroidreceptor-szupercsaládban találhatók és hatásuk átfed a család többi receptorára. Bár a D-vitamin a szervezetben is termelődik UV-sugárzás hatására, manapság elsősorban külső források biztosítják az emberi szervezet szükségletét. Ezen túlmenően a szükségletet messze meghaladó mennyiség kerül be a vitaminban panáceaként hívő emberek és gyermekeik szervezetébe. Hasonló a helyzet az A-vitamin esetében is, azzal a különbséggel, hogy ez kizárólag külső forrásból jut be a szervezetbe. Mindkét „vitamin” ma már csak tévedésből vagy „lustaságból” szerepel a vitaminok csoportjában, ugyanis mindkettő hormon (exohormon), mind receptoraik, mind hatásaik alapján. Mindkettő beleszól az emberi szervezet fejlődésébe, hiányuk alapján éppúgy, mint túltengésük esetében, és érett szervezetben is a hatásuk hormonszerü. Lényeges különbség azonban a klasszikus endokrin diszruptoroktól, hogy míg utóbbiak kis dózisban is megzavarják a normális endokrin egyensúlyt, addig e „vitaminok” korlátozott mennyiségben feltétlenül szükségesek az emberi szervezet homeosztázisához. Nem tudjuk azonban, hogy az ED-kategorizáláshoz mennyire szükséges a negatív hatás, mert például a fitoösztrogének esetében kifejezett pozitív hatások is megfigyelhetők. Az endokrindiszruptor-besorolás tehát egyrészt nemcsak minőség-, hanem mennyiségfüggő is, másrészt jelentősen függ attól az időtől, ami felismerésük óta rendelkezésünkre állt, tehát ami feltűnő volt, az rákerült a listára, ami nem, az még várat magára. Ugyanez a helyzet a nem szteroidreceptor-családban ható hormonszerú ED-kkel is, csak nagyon kevés adatunk van ezek romboló hatásáról, holott a vegyi szennyezés nem áll meg a szteroidoknál. Egy másik probléma, hogy egyes molekulákat annyira környezetünk állandó komponensének tekintünk, hogy részletes ED-vizsgálatukra nem is kerül sor. Ilyen például a benzpirén, amely akár természeti tevékenység, akár ipari vagy kommunális (például közlekedés) szennyezés részeként kerül környezetünkbe, alig kerül ED-szempontból vizsgálatra, holott receptora, éppúgy, mint a dioxiné is a szteroid-szupercsaládba tartozik és állatkísérletekben igencsak kártékonyak tudnak lenni. Kevesebb mint a népesség 7\%-a él olyan helyen Európában, ahol a benzpirén légkoncentrációja alacsonyabb, mint a hivatalosan elfogadható kockázati szint [58], ugyanakkor ebbe a szintbe az endokrin diszrupció még nem volt belekalkulálva.

Mindeddig nagyobbára a szteroidreceptor-szupercsalád tagjainak hatását befolyásoló anyagok kerültek EDként vizsgálatra, illetve sorolódtak be az endokrin disz- 
ruptorok közé, holott nagyon valószínű, hogy fehérje vagy aminosav típusú hormonok receptorainak (szintézisének, lebomlásának stb.) is vannak endokrin diszruptorai, amelyeket az iparban használnak fel, vagy éppen gyógyszerként adagolnak betegeknek. Ezek, figyelembe véve a nem szteroid hormonok szteroidoknál nagyobb számát, még több lehet, mint a szteroidrendszerre ható ED-ké. Ehhez járul, hogy nemcsak az ED-k listája hoszszabbodik, hanem a hormonoké is, illetve azon endogén anyagoké, amelyekről előbb-utóbb kiderül, hogy hormonként hatnak. Már jelenleg is vizsgálatra kerülnek ismert ED-k nem ismert célsejt esetében, például BPA hatása az obesitasra, de ez nem növeli az ED-k számát, ugyanakkor eddig ED-ként nem ismert molekulák hormonális hatása eddig nem vizsgált szervekre új típusú megközelítést jelenthet és növelheti az ED-k számát. Természetesen gazdaságosabb ED-ként ismert molekulák még nem célszervekre való ED-hatásának vizsgálata, de csak akkor, ha nem vesszük figyelembe, hogy az adott anyag kémiai szerkezete miatt lett ED, tehát ez meghatározza a célsejtet is. Mindenesetre vannak feltételezések a jelenleg ismert szteroidrendszerre ható ED-k és klaszszikusan nem szteroid befolyásolta kórképek kapcsolatáról, így ADHD, Parkinson-kór, Alzheimer-kór, diabetes, cardiovascularis kórképek és obesitas kerül említésre [59-61].

Miközben egyes szteroidok orvosi rendeletre (például hormonok) vagy a nélkül, de orvos-egészségügyi célra kerülnek felhasználásra (például a zsíroldékony „vitaminok”), nem vesszük figyelembe, hogy célsejtjeiken kívül endokrin diszruptorként hathatnak a szteroidreceptorszupercsalád egyéb tagjaira, illetve az azokat hordozó sejtekre. Ilyenek például a fogamzásgátló tabletták. Mivel tömegméretekben kerülnek felhasználásra, alkalmazásuk orvosi asszisztenciával végzett világméretű EDemberkísérletnek tekinthető, amelynek hatása valószínúleg nem múlik el nyomtalanul.

Az ED-k felismerésében alapvető szerepet játszott, hogy bizonyos kórképek ED-környezetben nagyobb mértékben jelentek meg, és ennek okát igyekeztek megtalálni. Előnyös volt, ha ezek a kórképek egyrészt könynyen felismerhetók voltak, másrészt olyan panaszokat okoztak, amelyek viselőiket orvossal való találkozásra késztették. Ugyancsak fontos szerepet játszott a vadvilágban bekövetkezett változások ismerete, mert az itt fellépő elváltozásokat rá lehetett vetíteni emberre is. Ilyen volt a vízi állatok, illetve madarak reproduktív károsodása, amelynek felismerése felhívta a figyelmet az embereket fenyegető veszélyekre is. Ennek alapján kerültek vizsgálatra azok az ED-k, amelyek az emberi reprodukciót és szexualitást veszélyeztetik. Ugyanakkor az, hogy a verebek esetleg néhány grammal súlyosabbak vagy a halak májenzimjeinek szintje akár a normális határokon belül alacsonyabb, nem feltünő és nem riasztja a környezetvédőket. Ami persze nem jelenti azt, hogy az ilyen (jövendőbeli) diszruptorok nem veszélyeztetik ugyanúgy az élővilágot, beleértve az embereket is, csak ez lassabban ható folyamat, tehát az ilyen, szteroid vagy nem szteroid jellegú (hatású) ED-k felismerése még várat magára. Az Európai Unió ED-listáján jelenleg 432 olyan anyag szerepel, amelyek közül 194-ről bizonyított az ED-hatás, a többi esetében alapos a gyanú, de még nincs elegendő bizonyíték. A lista nyitott, azaz további anyagok felvétele (esetleg törlése?) várható.

$\mathrm{Az}$ eddigieket figyelembe véve nem csodálható, hogy egyre több, felnóttkorban megjelenő (az adott időpontban ható faktorokra közvetlenül vissza nem vezethető) betegség okát az imprintingre legérzékenyebb perinatalis periódusra vezetik vissza [62-67]. Bár az ED-k tartós alkalmazása - mint láttuk - érett korban is kóros állapotok megjelenéséhez vezet, ez nem jelenti azt, hogy ha éppen nincs kimutatható ED, nem az okozta a betegséget, csak éppen nem akkor.

Bár az endokrin diszruptorok az endokrin rendszerre hatnak, nincs bizonyíték arra, hogy annak betegségét okoznák. Az endokrin mirigyekre hatva a mirigyek által szabályozott szervben vagy szervrendszerben jelenik meg a zavar, manifesztálódik a betegség. Ahhoz, hogy az endokrin mirigy betegsége lépjen fel, felsőbb szabályozásra (például a hypophysisre) ható ED lenne szükséges, de ilyet jelenleg nem ismerünk.

Ha elfogadjuk a kívülról bejutó A- és D-vitamint mint exohormonokat (különösen az A-vitamint, amelynek szervezetben termelődő megfelelője nincs is), amelyek az emlősszervezetek szülkségletévé váltak (annak ellenére, hogy tulajdonképpen endokrin diszruptorok), akkor nem zárható ki, hogy egyes ED-k ugyancsak internalizálódnak, azaz hozzájárulnak a normális fejlődéshez és funkcióhoz. Erre utalhat például a fitoösztrogének által kiváltott pubertas praecox, mert a menarche korábbi időpontja csak a jelenlegi átmeneti időszakban szokatlan jelenség, a későbbiekben a normális emberi fejlődés tankönyvi adatává válik. Ahogy az A- és D-vitamin megtalálta a helyét az emlősök - így az ember - fiziológiájában, ma még diszruptornak tekintett molekulák is annak részévé válhatnak, ha erre elegendő idő áll rendelkezésre és a szükséglet (szelekciós előny), illetve inger folyamatosan fennáll. Az A- és D-vitamin nemcsak azért kerültek a vitamin kategóriába, mert kívülről (a D-vitamin esetében ez nem is teljesen igaz) kerültek a szervezetbe, hanem mert az endokrin rendszer kritériumai még nem voltak világosak akkor, amikor e „vitaminok” hiányának betegségokozó hatása felmerült. A korrekció még mindig nem történt meg, holott világos, hogy a D-„,vitamin” hormon, és legnagyobb endokrin szervünk, a bőr terméke (is). Mindezek alapján nem lenne meglepő, ha például a fitoösztrogén genistein hosszabb idő után hormonná (exohormonná) válna, mint egy olyan molekula, ami ahhoz szükséges, hogy a pubertás az akkori (és nem a mostani) időpontban következzék be. A mozgásszervi rendszerről, érrendszerről stb. meglévő ismereteink hosszú idő óta stabilak, egy száz évvel ezelőtti anatómiai tankönyv lényegében ugyanazt tartalmazza róluk, mint a mai. Ez nem mondható el az endokrin rendszerről, 
amely folyamatos mozgásban van, rendszeresen új elemek (endokrin sejtek) és hormonok jelennek meg benne. A rendszer változásaiba „belefér” az „exohormon” fogalmának elfogadása és az endokrin diszrupturok egyes elemeinek bekebelezése is. Ez egyidejüleg azt is jelenti, hogy a klasszikus rendszerek (csontrendszer stb.) stabilitása mellett az endokrin rendszer, illetve az endogén hormonok hatása folyamatosan változni fog, elsősorban az ember teremtette környezet változékonysága miatt. Ennek jelei már most is világosan mutatkoznak, tehát figyelembe veendők a prevencióban és terápiában egyaránt.

Az endokrin diszruptorok globális és tömeges megjelenése jelentős veszélyeket hordoz. Még fenyegetőbb az általuk kiváltott imprinting öröklődése [68-72]. Még nincs elegendő ismeretünk annak megítélésére, hogy mennyire tartós az ily módon létrejött öröklődés, de az ismerethiány nem kizárólag az endokrin diszruptorokra vagy az általuk kiváltott hormonális imprintingre vonatkozik, hanem általában az epigenetikus öröklődésre, tehát amikor a DNS-bázisszekvencia megváltozása nélkül a DNS-expresszió szabályozásában történik öröklődő változás metiláció, hisztonacetiláció vagy speciális RNS-ek által. Azt már tudjuk, hogy ez néhány generáción át megjelenik az utódokban is, de nem volt még elég idő az emlősgenerációk sokaságának tanulmányozására. (Egysejtüekben azonban igen, és itt a hormonális imprinting hatása 1000 generáció után is megfigyelhető [73].) Az azonban máris nyilvánvaló, hogy ahol öröklődött az epigenetikus változás, ott eltérő a reakció az újabb hormonális impulzusokra, tehát bizonyos gyógyszerekre, illetve újabb ED-kre is. Ha a fertilitás van érintve, az demográfiai problémákat hív elő. Ha a változás tartóssága vetekszik a mutációkkal, akkor ennek evolúciós jelentősége is lehet.

\section{Következtetés}

Az emberiség jelenleg a klímaváltozás hatásaitól retteg és nem is indokolatlanul. Erről az emberek szinte mindegyike tud. A politikusok is beszélnek róla és próbálnak tenni ellene. Emellett azonban egyéb globális változások is fenyegetik az emberiséget. Ezek egyike, de lehet, hogy a legfontosabbika, az egyre inkább mesterségessé váló környezet visszahatása az emberi szervezetre, ezen belül az endokrin diszruptorok hatása, aminek következtében egyáltalán nem biztos, hogy a klímaváltozás a jelenlegi de máris változó - fiziológiai paraméterekkel rendelkező emberiséget fogja sújtani.

Anyagi támogatás: A közlemény megírása anyagi támogatásban nem részesült.

A szerző a cikk végleges változatát elolvasta és jóváhagyta.

Érdekeltségek: A szerzőnek nincsenek érdekeltségei.

\section{Irodalom}

[1] Csaba G. Phylogeny and ontogeny of hormone receptors: the selection theory of receptor formation and hormonal imprinting. Biol Rev Camb Biol Soc. 1980; 55: 47-63.

[2] Csaba G. Hormonal imprinting: its role during the evolution and development of hormones and receptors. Cell Biol Int. 2000; 24: 407-414.

[3] Csaba G. The present state in the phylogeny and ontogeny of hormone receptors. Horm Metab Res. 1984; 16: 329-335.

[4] Csaba G. Transgenerational effects of perinatal hormonal imprinting. In: Tollefsbol T. (ed.) Transgenerational epigenetics. Academic Press, New York, 2014; pp. 255-264.

[5] Karabélyos C, Csaba G. Effect of digoxin imprinting in adolescence on the sexual behavior of adult rats. Acta Physiol Hung. 1999; 86: 23-28.

[6] Neri A, Aygen M, Zukerman Z, et al. Subjective assesment of sexual dysfunction of patients on long-term administration of digoxin. Arch Sex Behav. 1980; 9: 343-347.

[7] Langston N. Rachel Carson's legacy: Endocrine disrupting chemicals and gender concerns. GAIA 2012; 21: 225-229.

[8] Marty MS, Carney EW, Rowlands JC. Endocrine disruption: historical perspectives and its impact on the future of toxicology testing. Toxicol Sci. 2011; 120(Suppl 1): S93-S108.

[9] WHO European Commission. http//ec.europa eu/environment/chemicals/endocrine definitions/endodis-an.htm

[10] Canadian Centre for Occupational Health and Safety. https// www.coohs.ca/oshanswers/chemicals/endocrine.html

[11] Dudutz G, Kincses-Ajtay M, Csép K. More important endocrine disruptors and their effects on living organisms. [Fontosabb endokrin diszruptor vegyületek és az élő szervezetekre kifejtett hatásaik.] Orvostud Ért. 2009; 82: 156-164. [Hungarian]

[12] Munteanu C, Hoteteu M. Estrogenic compounds - endocrine disruptors. Balneo-Research J. 2011; 2: 115-118.

[13] Mangelsdorf DJ, Thummel C, Beato M, et al. The nuclear receptor superfamily: the second decade. Cell 1995; 83: 835-839.

[14] Mnif W, Hadi Hassine AI, Bouaziz A, et al. Effect of endocrine disruptor pesticides: A review. Int J Environ Res Public Health 2011; 8: 2265-2303.

[15] Csaba G, Karabélyos C. Pubertal benzpyrene exposition decreases durably the sexual activity of the adult male and female rats. Horm Metab Res. 1995; 27: 279-282.

[16] Csaba G, Inczefi-Gonda Á. Molecules acting on receptor level at weaning, durably influence liver glucocorticoid receptors. Acta Physiol Hung. 2005; 92: 33-38.

[17] Tekes K, Hantos M, Gyenge M, et al. Prolonged effect of stress at weaning on the brain serotonin metabolism and sexuality of female rats. Horm Metab Res. 2006; 38: 799-802.

[18] Nugent BM, Tobet SA, Lara HE, et al. Hormonal programming across the lifespan. Horm Metab Res. 2012; 44: 577-586.

[19] Gaál A, Csaba G. Testosterone and progesterone level alterations in the adult rat after retinoid (retinol or retinoic acid) treatment in neonatal and adolescent age. Horm Metab Res. 1998; 30: $487-489$

[20] Csaba G, Inczefi-Gonda Á. Effect of vitamin D3 treatment in the neonatal or adolescent age (hormonal imprinting) on the thymic glucocorticoid receptor of the adult male rat. Horm Res. 1990; 51: 280-283.

[21] Goetz F, Mitroskhin A, Patchev AV, et al. Significance of neonatal steroid imprinting and of peripubertal growth hormone excess for the development of prostatic hyperplasia in the rat. Endocrine Abstracts 2006; 11: 555.

[22] Akingbemi BT, Hardy MP. Oestrogenic and antiandrogenic chemicals in the environment: effects on male reproductive health. Acta Med. 2001; 33: 391-403.

[23] Crews F, He J, Hodge C. Adolescent cortical development. A critical period of vulnerability for addiction. Pharmacol Biochem Behav. 2007; 86: 189-199. 
[24] Hampl R, Kubátová J, Stárka L. Steroids and endocrine disruptors - History, recent state of art and open questions. J Steroid Biochem Mol Biol. 2016; 155: 217-223.

[25] Csaba G, Karabélyos C. Effect of single neonatal treatment with the soy bean phytosteroid, genistein on the sexual behavior of adult rats. Acta Physiol Hung. 2002; 89: 463-470.

[26] Patisaul HB, Jefferson W. The pros and cons of phytoestrogens. Front Neuroendocrinol. 2010; 31: 400-419.

[27] Rietjens IM, Louisse J, Beekmann K. The potential health effects of dietary phytoestrogens. Br J Pharmacol. 2017; 174: 12631280.

[28] Patisaul HB, Adewale HB. Long-term effects of endocrine disruptors on reproductive physiology and behavior. Front Behav Neurosci. 2009; 29: 10.

[29] Marques-Pinto A, Carvalho D. Human infertility, are endocrine disruptors to blame? Endocr Connect. 2013; 2: R15-R29.

[30] Aksglaede L, Juul A, Leffers H, et al. The sensitivity of the child to sex steroids: possible impact of exogenous estrogens. Hum Reprod Update 2006; 12: 341-349.

[31] Li D, Zhou Z, Qing, D, et al. Occupational exposure to bisphenol-A (BPA) and the risk of self-reported male sexual dysfunction. Hum Reprod. 2009; 25: 519-527.

[32] Hainer R. Study links BPA in plastics to erectile dysfunction. Health.com, November 11, 2009. Updated 2017 GMT (0417 HKT).

[33] Fratrić I, Živković D, Vukmirović S. Human exposure to endocrine disrupting chemicals as a prenatal risk factor for cryptorchidism. Pediatr Croat. 2015; 59: 19-24.

[34] Virtanen HE, Adamsson A. Cryptorchidism and endocrine disrupting chemicals. Mol Cell Endocrinol. 2012; 355: 208-220.

[35] Bay K, Andersson AM. Human testicular insulin-like factor 3: in relation to development, reproductive hormones and andrological disorders. Int J Androl. 2011; 34: 97-109.

[36] Balthazart J. Minireview: Hormones and human sexual orientation. Endocrinology 2011; 152: 2937-2947.

[37] Johnson C. Endocrine disruptors and the transgendered. Washington Free Press, 2002 March.

[38] Sonnenschein C, Soto AM. An updated review of environmental estrogen and androgen mimics and antagonists. J Steroid Biochem Mol Biol. 1998; 65: 143-150.

[39] Csaba G, Karabélyos C, Dalló J. Fetal and neonatal action of a polycyclic hydrocarbon (benzpyrene) or a synthetic steroid hormone (allylestrenol) as reflected by the sexual behaviour of adult rats. J Dev Physiol. 1993; 19: 67-70.

[40] Csaba G, Karabélyos C. Transgenerational effect of a single neonatal benzpyrene treatment (imprinting) on the sexual behavior of adult female rats. Hum Exp Toxicol. 1997; 16: 553-556.

[41] Boas M, Feldt-Rasmussen U, Main KM. Thyroid effects of endocrine disrupting chemicals. Mol Cell Endocrinol. 2012; 355: 240-248.

[42] Boas M, Main KM, Feldt-Rasmussen U. Environmental chemicals and thyroid function: an update. Curr Opin Endocrinol Diabetes Obes. 2009; 16: 385-391.

[43] Duntas LH. Chemical contamination and the thyroid. Endocrine 2015; 48: 53-64.

[44] Gutleb AC, Cambier S, Serchi T. Impact of endocrine disruptors on the thyroid hormone system. Horm Res Paediatr. 2016; 86: 271-278

[45] Boas M, Feldt-Rasmussen U, Skakkebaek NE, et al. Environmental chemicals and thyroid function. Eur J Endocrinol. 2006; 154: 599-611.

[46] Schmutzler C, Gotthardt I, Hofmann PJ, et al. Endocrine disruptors and the thyroid gland - a combined in vitro and in vivo analysis of potential new biomarkers. Environ Health Perspect. 2007; 115(Suppl 1): 77-83.

[47] Takahama K, Shirasaki T. Endocrine disruptors and brain estrogen receptors: the current state of behavioral, neurochemical, and molecular biological studies. Nihon Shinkei Seishin Yakurigaku Zasshi 2001; 21: 103-111.

[48] Palanza P, Gioiosa L, vom Saal FS, et al. Effects of developmental exposure to bisphenol A on brain and behavior in mice. Environ Res. 2008; 108: 150-157.

[49] Van der Akker EL, Weisglas-Kuperus N. Sexual differentiation of the human brain. Hormonal controls and effects of endocrine disruptors. In: Lewis M, Kestler L. (eds.) Gender differences in prenatal substance exposure. American Psychological Association, Washington, DC, 2012; pp. 207-215.

[50] Evans SF, Kobrosly RW, Barrett ES, et al. Prenatal bisphenol An exposure and maternally reported behavior in boys and girls. Neurotoxicology 2014; 45: 91-99.

[51] Mustieles V, Pérez-Lobato R, Olea N, et al. Bisphenol A: Human exposure and neurobehavior. Neurotoxicology 2015; 49: 174184.

[52] Csaba G, Tekes K. Is the brain hormonally imprintable? Brain Dev. 2005; 27: 465-471.

[53] Sisk CL, Zehr JL. Pubertal hormones organize the adolescent brain and behavior. Front Neuroendocrinol. 2005; 26: 163-174.

[54] Chalubinski M, Kowalski ML. Endocrine disrupters - potential modulators of the immune system and allergic response. TOC 2006; 61: 1326-1335.

[55] Rogers JA, Metz L, Yong VW. Review: Endocrine disrupting chemicals and immune responses: a focus on bisphenol-A and its potential mechanisms. Mol Immunol. 2013; 53: 421-430.

[56] Kuo CH, Yang SN, Kuo PL, et al. Immunomodularory effects of environmental endocrine disrupting chemicals. Kaohsiung J Med Sci. 2012; 28(Suppl): S37-S42.

[57] Csaba G. Hormonal imprinting: phylogeny, ontogeny, diseases and possible role in present-day human evolution. Cell Biochem Funct. 2008; 26: 1-10.

[58] Guerreiro CB, Horálek J, de Leeuw F, et al. Benzo(a)pyrene in Europe: Ambient air concentrations, population exposure and health effects. Environ Pollut. 2016; 214: 657-667.

[59] Jones DC, Miller GW. The effects of environmental neurotoxicants on the dopaminergic system. A possible role in drug addiction. Biochem Pharmacol. 2008; 76: 569-581.

[60] Chevalier N, Fénichel P. Endocrine disruptors: A missing link in the pandemy of type 2 diabetes and obesity. Presse Med. 2016; 45: 88-97.

[61] De Cock M, Maas YG, van de Bor M. Does perinatal exposure to endocrine disruptors induce autism spectrum and attention deficit hyperactivity disorders? Review. Acta Paediatr. 2012; 101: 811-818.

[62] Dörner G. Environment and gene-dependent human ontogenesis, sociogenesis and phylogenesis (eco-geno-onto-socio-phylogenesis). Neuro Endocrinol Lett. 2004; 25: 164-168.

[63] Holmang A. Perinatal origin of adult disease. Scand Cardiovasc. 2001; 35: 178-185.

[64] Tchernitchin AN, Tchernitchin NN, Mena MA, et al. Imprinting: perinatal exposures cause the development of diseases during the adult age. Acta Biol Hung. 1999; 50: 425-440.

[65] Csaba G. The faulty perinatal hormonal imprinting as functional teratogen. Curr Pediatr Rev. 2016; 12: 222-229.

[66] Heindel JJ, Skalla LA, Joubert BR, et al. Review of developmental origins of health and disease publications in environmental epidemiology. Reprod Toxicol. 2017; 68: 34-48.

[67] Csaba G. Immunoendocrinology: faulty hormonal imprinting in the immune system. Acta Microbiol Hung. 2014; 61: 89-106.

[68] Anway MD, Cupp AS, Uzumcu M, et al. Epigenetic transgenerational actions of endocrine disruptors and male fertility. Science 2005 ; 308 : 1466-1469.

[69] Csaba G, Inczefi-Gonda Á. Direct and transgenerational effect of benzpyrene treatment at adolescent age on the uterine estrogen receptor and thymic glucocorticoid receptor of the adult rat. Acta Physiol Hung. 1999; 86: 29-36. 
[70] Csaba G. The biological basis and clinical significance of hormonal imprinting, an epigenetic process. Clin Epigenetics 2011; 2: 187-196.

[71] Skinner MK. Endocrine disruptor induction of epigenetic transgenerational inheritance of disease. Mol Cell Endocrinol. 2014; 398: 4-12.

[72] Xin F, Susiarjo M, Bartolomei MS. Multigenerational and transgenerational effects of endocrine disrupting chemicals: A role for altered epigenetic regulation? Semin Cell Dev Biol. $2015 ; 43: 66-75$.
[73] Kőhidai L, Lajkó E, Pállinger É, et al. Verification of epigenetic inheritance in a unicellular model system: multigenerational effects of hormonal imprinting. Cell Biol Int. 2012; 36: 951-959.

(Csaba György dr., Budapest, Pf. 370, 1445 e-mail: csagyor@dgci.sote.hu)
PAPP ZOLTÁN

\section{A SZÜLÉSZET- NÖGYÓGYÁSZAT TANKÖNYVE}

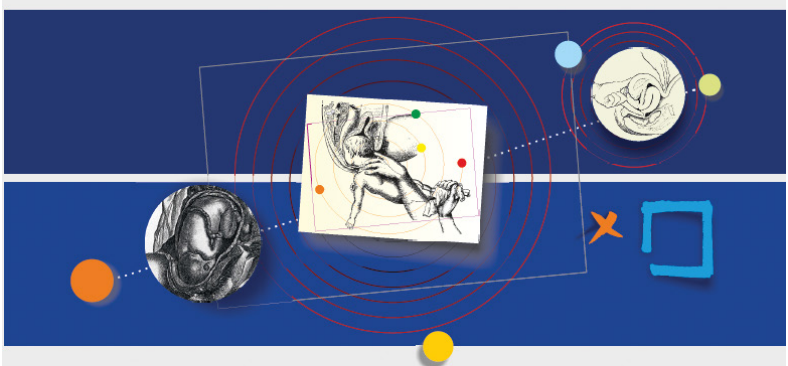

(5)

Semmelweis Kiadó

\section{Megjelent az új szülészet-nőgyógyászati tankönyv!}

Papp Zoltán professzor klinikaigazgatói nyugdíjazása (2007) után az elmúlt 10 évben sem hagyta abba a szülészetnőgyógyászati ténykedését. Így ötvenéves szülészorvosi pályafutása során szerzett klinikai, vezetői, oktatói és kutatói gyakorlata, funkcionális morfológiai és klinikusi pszichoszomatikus szemlélete, mütéttani felkészültsége, valamint pedagógusi öröksége és tapasztalata összeérett egy tankönyvvé.

A könyv megvásárolható a Semmelweis Egyetem Nagyvárad téri Elméleti Tömbjében, a Semmelweis Könyvesboltban. 